\title{
Introduction to the EPC Mode Construction Supply Chain Cost Management
}

\author{
Binmei ZHU, Liping REN \\ school of management, Xi'an University of Architecture and Technology, Xi'an, Shaanxi, China \\ Weipeng TONG \\ Xi'an jiangong chenghang real estate co.ltd, Xi'an Shaanxi, China
}

\begin{abstract}
: this paper discusses the current problems existing in the construction enterprises cost control in the EPC mode, discusses the construction enterprises to take advantage of the supply chain cost management, and points out the construction enterprises want to gain long-term development in the fierce competition and competitive advantage, to supply chain cost management can effectively reduce the cost, realize the maximization of the value of the whole chain, finally to achieve win-win situation.
\end{abstract}

KEYWORD: the EPC mode; construction supply chain; supply chain cost management

\section{THE CHARACTERISTICS OF THE EPC}

Over the past twenty years, EPC (Engineering Procurement Construction) mode in a turn-key contracting mode more and more get the favor of the owner, compared with the traditional contract mode, owner of the most of the Engineering risk shifting to Engineering general contractor, general contractor for contracting Engineering quality, safety, schedule, cost will be entirely responsible for. Because in the process of bidding is not adopt the method of the list valuation, leading to increased difficulties of bidding process, and increased uncertainty.

\section{THE PRESENT SITUATION USING EPC MODE CONSTRUCTION ENTERPRISE COST MANAGEMENT}

Although the EPC mode cost control is based on the whole process of the whole project management, but often only pay attention to the stages in the process of actual implementation of cost control, such as simply focus on design, material procurement, construction and other various stages of the cost control problems, cause each stage of cost management is not harmonious, simple one stage cost management is outstanding, but the cost of the project is still high, management become a mere formality. and the EPC pattern development time is not long in our country, the management idea, management method, management technology, platform, management personnel quality, ect and also abroad there is a big gap. so the EPC mode still have considerable controllable cost management space.

\subsection{Desing and project cost management consciousness is weak}

Everyone should have cost consciousness in the cost control. But in the fact, the designers generally only consider the requirements of the product functional, and rarely pay attention to the link of the design requirements and the procurement. not take control of the concept of cost into consideration, often cause conflict with actual construction and design, serious can affect the construction period, increased management costs and transaction costs rise.

Because of the general contractor often focus on engineering quality and safety, the cost management is often not enough, and the cost control also more relaxed on the appraisal system, as long as for a limited time period to complete the contract content, with good quality cost control can not be considered. So in cost management of the implementation of the actual phase, liability costs tend to become a mere formality.

\subsection{The cost control system is not perfect}

Good cost control system is the precondition of cost under control. At present most enterprises just stop at simple stage of rewards and punishment, no complete and improve the cost control system, also does not have to form a complete set of incentive mechanism and operation mechanism, if any, had no 
real implementation, just put such operation mechanism on the shelf.

\subsection{Information sharing mechanism is not sound, often cause high cost}

Timely flow of information sharing is the premise to reduce unnecessary waste, however, EPC mode only exists in the enterprise internal information sharing, the supplier can't grasp the demand of the general contractor information in time, may cause delayed delivery or delivery in advance, general contractor inventory of unreasonable phenomenon, increased management costs and warehousing costs. With the general contractor and subcontractor information not unobstructed between may cause the construction period and quality cannot be guaranteed.

\section{THE ADVANTAGE OF CONSTRUCTION SUPPLY CHAIN COST MANAGEMENT IN THE EPC MODE}

Supply chain management thinking is to stand at the height of strategy, establish a strategic cooperative partnership on the chain, not only consider the enterprise internal cost, also consider the cost of the whole chain, it into the idea of lean cost management, and the pursuit of each participating nodes in the chain enterprises the cost of the optimal, continually eliminate not value-added homework for the node enterprises, put an end to waste, so as to reduce the cost of the supply chain, to achieve maximum efficiency, maximum limit satisfy each node enterprises personalized, diversified services, the most always achieve the enhancement purpose to the enterprise competitiveness, in the supply chain cost management, each node enterprise cooperation, so that the parties together in a win-win situation to improve its own strategic position, so the cost of supply chain management need to work together to achieve each node enterprise, more complicated than the traditional cost management.

Building supply chain is defined in the project to the project operation until the expansion and removal of the entire project life cycle, all the participants by the project, in order to satisfy the demands of the owner, to maximize the overall benefit as the goal of a functional network.

EPC mode construction is the general contractor as the core enterprise of supply chain, upstream enterprises as material suppliers, equipment suppliers, downstream level, labor subcontractor for engineering subcontractor property, such as building supply chain structure chart for general contracting mode.

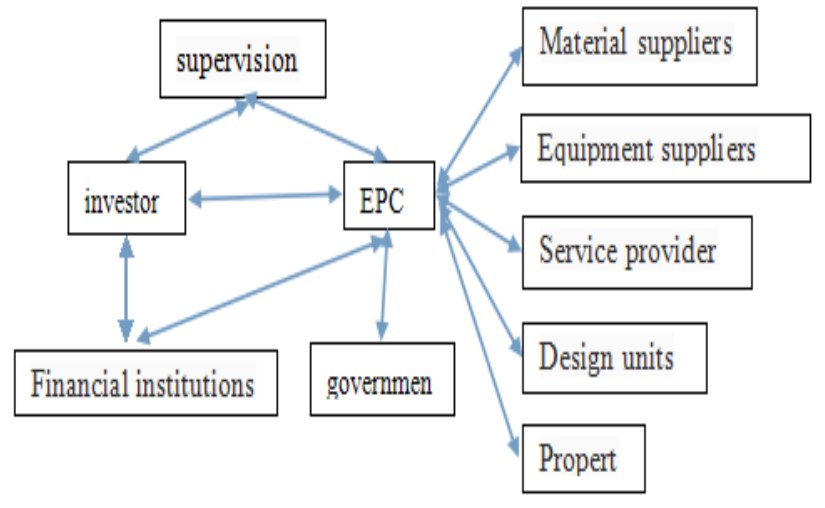

Figure 3-1 construction supply chain structure under general contracting mode $* * *$

\section{THE MAIN CONTENT OF CONSTRUCTION SUPPLY CHAIN COST MANAGEMENT}

Construction supply chain and traditional supply chain, logistics, information flow, capital flow between stakeholders. So to cost management is to manage the cost of the chain.

\subsection{The logistics cost of construction supply chain management}

Construction in the supply chain logistics mainly refers to the general contractor for the purchase of materials and equipment suppliers, and contractors and distribution logistics between labor subcontractor. Logistics cost refers to the cost of formed during this period. Mainly includes the purchase cost, inventory cost, ordering cost, transportation cost, management cost, etc., and transportation costs, management costs are fixed, the supply chain cost management in order the economic order quantity (EOQ), effectively reduce the order cost, and in the inventory management by way of vendor managed inventory (VMI), research shows that this method effectively reduces the upstream and downstream enterprise's inventory cost, make the upstream and downstream enterprises can achieve benefit alliance.

\subsection{The information cost of construction supply chain management}

Asymmetry of information sharing is the important cause of the high cost, information cost of the supply chain is to point to set up the chain information sharing mechanism as well as information on the cost in the process of delivery. Under the supply chain cost management, set up the mechanism of the nodes involved in the enterprise information sharing platform, prompt information in each node enterprise flows smoothly in a timely manner, is able to adjust the conflict, reduce the transaction cost and change in the collaboration. 


\subsection{The risk cost of the construction supply chain management}

In EPC mode, the owner is only put forward the whole project function and quality of the overall requirements, the general contractor is responsible for the design, procurement, construction and delivery operation, the owner is not involved in the specific process of project implementation, so the whole project most controllable and uncontrollable risk passed on to the general contractor, and other forms of contract, general contractor to assume the entire risk as to the every stage of the design, procurement and construction, once the phase of the risk is not dispersed in time, will bring great loss to the contractor. Construction cost of supply chain risk management is refers to in order to reduce and prevent or stop the project risk occurred during the operation, to establish risk prevention and control measures of cost, so that we can timely found potential risk, control, transfer, or spread risk, to reduce the risk to the enterprise of heavy losses.

When listing facts use either the style tag List signs or the style tag List numbers.

\subsection{The transaction cost of construction supply chain management}

Communication between internal departments, external cost refers to the owner and the contractor, general contractor and the cost of communication between suppliers and subcontractors forming. Due to the supply chain cost management is to stand in the perspective of the strategic thinking, thoughtful in design phase, the full consultation, to ensure the smooth progress of the follow-up work to reduce the repeated communication and consultation, design change by reducing the internal transaction costs. With sound information sharing mechanism, can reduce the transaction costs.

\section{CONCLUSION}

The goal is to maximize the overall value of supply chain of supply chain management, the goal of construction supply chain cost management is the cost of the whole chain node enterprise overall optimal, maximize the chain profit. It can solve the present problems of cost management, EPC mode, reduce the cost of core enterprise and a fixed cost of the contract, realize the maximization of the profit of core enterprise, the core enterprise in the fierce competition of construction market to obtain larger competitive advantage.

\section{REFERENCES}

[1] Gui Liangjun, Supply chain cost management theory and method of research. Accounting research 2005. 51 52

[2] Zhao Xiaofei, The comparative research on construction supply chain management between China and Foreign countries. 2006 5 6

[3] Chen Yikun, Optimization of the supply chain management research in China. 2013 16 21 